\title{
Is Surgical Resection Justified for Advanced Intrahepatic Cholangiocarcinoma?
}

\author{
Tomoaki Yoh Etsuro Hatano Kenya Yamanaka \\ Takahiro Nishio Satoru Seo Kojiro Taura Kentaro Yasuchika \\ Hideaki Okajima Toshimi Kaido Shinji Uemoto \\ Department of Surgery, Graduate School of Medicine, Kyoto University, Kyoto, Japan
}

\section{Key Words}

Intrahepatic cholangiocarcinoma - Intrahepatic metastasis · Lymph node metastasis .

Surgical resection · Vascular invasion

\begin{abstract}
Backgrounds: Prognosis for patients with advanced intrahepatic cholangiocarcinoma (ICC) with intrahepatic metastasis (IM), vascular invasion (VI), or regional lymph node metastasis (LM) remains poor. The aim of this study was to clarify the indications for surgical resection for advanced ICC. Methods: We retrospectively divided 213 ICC patients treated at Kyoto University Hospital between 1993 and 2013 into a resection ( $n=164)$ group and a non-resection ( $n=49$ ) group. Overall survival was assessed after stratification for the presence of IM, VI, or LM. Results: Overall median survival times (MSTs) for the resection and non-resection groups were 26.0 and 7.1 months, respectively $(p<0.001)$. After stratification, MSTs in the resection and non-resection groups, respectively, were 18.7 vs. 7.0 months for patients with IM $(p<0.001), 23.4$ vs. 5.7 months for those with VI $(p<0.001)$, and 12.8 vs. 5.5 months for those with LM $(p<0.001)$. Conclusion: When macroscopic curative resection is possible, surgical resection can be justified for some advanced ICC patients with IM, VI, or LM.
\end{abstract}




\section{Introduction}

Intrahepatic cholangiocarcinoma (ICC), i.e., cholangiocarcinoma located near the secondary or more distal branches of the biliary tree, is the second most common primary liver cancer after hepatocellular carcinoma [1,2]. The incidence of ICC is increasing globally [3]. Surgical resection is the mainstay of curative treatment for selected ICC patients, and 5-year survival rates of $15 \%-40 \%$ have been reported [4-8]. Outcomes after the surgical resection of ICC are relatively well reported, and previous cohorts have identified intrahepatic metastasis (IM), vascular invasion (VI), and lymph node metastasis (LM) as significant negative prognostic factors [4-7]. Accordingly, the European Association for the Study of Liver (EASL) guidelines for ICC [8] discourage surgical resection for advanced ICC patients with a clinical diagnosis of IM, VI, or LM.

Few studies [7, 9] have compared the outcomes of patients undergoing surgical resection for ICC with those undergoing non-surgical treatments. Moreover, the survival benefits of surgical resection have not been compared among patients with IM, VI, or LM. At Kyoto University Hospital, advanced ICC patients with IM, VI, or LM are considered for surgery if macroscopically curative resection is possible. In the present study, we analyzed the outcomes of resection in ICC patients at our institution and reviewed the associated literature to assess the indication of surgical resection for advanced ICC patients with IM, VI, or LM.

\section{Patients and Methods}

\section{Study Design}

The present historical cohort comprised all 213 patients who were diagnosed with ICC in the Department of Surgery, Kyoto University Hospital, from January 1993 to December 2013. ICCs were defined as tumors that had developed from the intrahepatic bile duct at the secondary or more-distal branches. Advanced ICC was defined as those with IM, VI, or LM. Advanced ICCs were found in 145 patients (68\%), and non-advanced ICCs were found in 68 (32\%) patients. In total, 164 patients underwent surgical resection and 49 underwent non-surgical treatments. Consequently, patients were divided into resection $(n=164)$ and non-resection $(n=49)$ groups. Patients in whom macroscopically curative resection was deemed possible were indicated for surgical resection (depending on the patients' overall condition and/ or liver function). Cases were considered to be inoperable when bulky para-aortic lymph nodes or uncontrollable distant metastases were observed. ICC was diagnosed in the non-resected patients using radiography. In resected patients, ICC was confirmed by histopathologic analysis. The study protocol was approved by the ethical committee of the Graduate School of Medicine, Kyoto University (E2334).

\section{Study Variables}

Radiological and clinicopathological data were collected from medical records at Kyoto University Hospital, and patients' age, gender, Child-Pugh classification, serum CA19-9 levels, IM, VI, LM, distant metastasis, and clinical stage were recorded. Cancer stages were categorized as I, II, III, or IV according to the seventh edition of the American Joint Committee on Cancer/International Union Against Cancer classification [10]. In both groups, IM, VI, and LM status was determined using pretreatment computed tomography and/or magnetic resonance imaging examinations. ${ }^{18} \mathrm{~F}$-Fluorodeoxyglucose positron emission tomography-computed tomography was introduced in 2002 for preoperative evaluation [11]. Distant metastases were detected using radiology or exploratory laparotomy. Follow-up data were updated on January 1, 2015.

\section{Statistical Analysis}

Overall survival (OS) was defined as the period between the date of initial hospitalization and the day of death from any cause. Survival curves were estimated using the Kaplan-Meier method and were compared using the log-rank test. ICC patients were then stratified into groups with IM, VI, or regional $\mathrm{LM}$, and univariate and multivariate hazard ratios [with 95\% confidence intervals (CI)] were estimated using Cox models. Five potential confounders were inserted into the Cox models: surgical resection, IM, VI, LM, and distant metastasis [4-8]. Continuous variables were expressed as the median (range) and 
Table 1. Clinical characteristics of 213 ICC patients treated at Kyoto University Hospital between 1993 and 2013

\begin{tabular}{|c|c|c|c|}
\hline Variable & $\begin{array}{l}\text { Resection } \\
n=164\end{array}$ & $\begin{array}{l}\text { Non-resection } \\
\mathrm{n}=49\end{array}$ & p-value \\
\hline Age (years) & & & 0.26 \\
\hline Median & 65 & 67 & \\
\hline Range & $26-84$ & $36-82$ & \\
\hline Gender & & & 0.91 \\
\hline Male & $99(60 \%)$ & $30(61 \%)$ & \\
\hline Child-Pugh classification B/C & $6(4 \%)$ & $12(24 \%)$ & $<0.001^{*}$ \\
\hline CA19-9 levels (U/ml) & & & $0.0010^{*}$ \\
\hline Median & 60.1 & 436.1 & \\
\hline Range & $0-29682$ & $0-40357$ & \\
\hline IM & $36(22 \%)$ & $19(39 \%)$ & $0.018^{*}$ \\
\hline Tumor distribution: bilobar & $23(64 \%)$ & $14(74 \%)$ & 0.46 \\
\hline Tumor number $\geq 5$ & $11(31 \%)$ & $8(42 \%)$ & 0.39 \\
\hline VI & $66(40 \%)$ & $30(61 \%)$ & $0.0096^{*}$ \\
\hline Portal venous invasion & $56(34 \%)$ & $30(61 \%)$ & $<0.001^{*}$ \\
\hline Hepatic venous invasion & $28(17 \%)$ & $18(37 \%)$ & $0.0033^{*}$ \\
\hline Regional LM & $46(28 \%)$ & $17(35 \%)$ & 0.38 \\
\hline Distant metastasis & $15(9 \%)$ & $31(63 \%)$ & $<0.001^{*}$ \\
\hline AJCC/UICC classification & & & $0.031^{*}$ \\
\hline Stage I & $26(16 \%)$ & $0(0 \%)$ & \\
\hline Stage II & $19(12 \%)$ & $7(14 \%)$ & \\
\hline Stage III & 27 (16\%) & $10(20 \%)$ & \\
\hline Stage IV & $92(56 \%)$ & 32 (65\%) & \\
\hline
\end{tabular}

*Significantly different. AJCC/UICC=American Joint Committee on Cancer/Union for International Cancer Control.

were compared using the Mann-Whitney U test. Categorical variables were compared using $\chi^{2}$ tests. All analyses were two sided, and differences were considered significant when $\mathrm{p}<0.05$. Statistical analyses were performed using JMP ver. 11.2 software (SAS, Cary, NC, USA).

\section{Results}

\section{Patient Characteristics}

Baseline clinical features of the patients are listed in table 1. The patients in the nonresection group showed high serum CA19-9 levels, and patients with Child-Pugh B/C, IM, VI, and distant metastasis and stage II, III, or VI patients were more numerous in the non-resection group. Distant metastasis, intrahepatic spread, locally advanced disease, and the patients' overall condition precluded surgery in $31,14,13$, and 3 cases, respectively (they overlapped). Treatments for the non-resected patients included systemic chemotherapy $(n=36)$, intra-arterial therapy $(n=9)$, radiotherapy $(n=1)$, and best supportive care $(n=3)$. In the resection group, 14 patients with resectable or controllable distant metastasis (stable disease with non-surgical treatment) underwent surgical resection, of which 12 had non-regional LM, 2 had controllable lung metastasis, and 2 had localized peritoneal metastasis (with some overlap). In 
addition, 51 patients in the resection group (31\%) underwent adjuvant gemcitabine-based chemotherapy [12].

\section{Survival after Surgical Resection for Advanced ICC}

OS was significantly better in the resection group than in the non-resection group [median survival times (MSTs), 26.0 vs. 7.1 months; 3/5-year survival, $43 \% / 35 \%$ vs. $3.7 \% / 0 \%$; $\mathrm{p}<0.001]$. Eight patients who underwent surgical resection died during the postoperative course. In the IM, VI, and LM subgroups, MSTs for the resection and the non-resection groups were 18.7 vs. $7.0(\mathrm{p}<0.001), 23.4$ vs. 5.7 ( $\mathrm{p}<0.001)$, and 12.8 vs. 5.5 months $(\mathrm{p}<0.001)$, respectively (fig. 1a-c). Further, we analyzed OS according to the number of risk factors. In patients with one, two, and three risk factors, MSTs for the resection and the non-resection groups were 20.3 vs. 10.0 ( $\mathrm{p}<0.001), 16.9$ vs. 5.5 ( $\mathrm{p}<0.001$ ), and 14.1 vs. 7.6 months ( $\mathrm{p}=0.032$ ), respectively (fig. $2 \mathrm{a}-\mathrm{c}$ ). Multivariate analysis showed that the hazard ratio of surgical resection was 0.32 [95\% CI, 0.19-0.53]. LM (hazard ratio: 1.87, 95\% CI: 1.25-2.76) was another independent prognostic factor (table 2). These results indicate that surgical resection for ICC patients with IM, VI, or LM provided more survival benefit than non-surgical treatments.

\section{Discussion}

IM, VI, and LM were identified as important prognostic factors in recent studies $[4-7,13]$ and in a systematic review of surgical resection outcomes [14], and these findings were reflected in the EASL guidelines [8]. The EASL guidelines discourage surgical resection in clinically advanced ICC patients with IM, VI, or LM; however, our data suggest that surgical resection provides marked survival benefits over non-surgical treatments, even for advanced ICC patients with IM, VI, or LM. In our institution, MSTs of advanced ICC patients with clinical IM, VI, or LM were 18.7, 23.4, and 12.8 months after surgical resection and 7.0, 5.7, and 5.5 months after non-surgical treatments, respectively. Moreover, surgical resection independently benefitted survival, regardless of the presence of clinical IM, VI, or LM.

In the current study, the comparison of surgical resection and non-surgical treatments was influenced by patient selection bias. To assess the strength of our assertions, we conducted a literature review. The PubMed database was systematically searched for articles published in English between January 2000 and January 2015 using the term "ICC". As a result, 1178 studies were retrieved from database searches, and 9 were retrieved from reference lists. These studies were subjected to the following exclusion criteria: (1) less than 50 patients, (2) no assessment of prognostic factors, (3) mixed series of patients with other diseases, (4) performance of liver transplantation, and (5) performance of ablation therapy. Of the 1187 studies considered, 26 were deemed eligible according to our review criteria and are described in table 3. Reported MSTs were 25.5 months in resected ICC patients and 12.2 months in non-resected ICC patients. In stratified analyses, MSTs for resected and nonresected patients, respectively, were 12.5 and 5.2 months for patients with IM and 10.7 and 5.9 months for patients with LM. No studies reported MSTs of non-resected patients with VI; however, the MST for resected patients with VI was 15.5 months. Taken together, surgical resection in ICC patients with IM, VI, or LM provided a survival benefit over non-surgical treatments in all included studies. Therefore, careful selection and curative resection can improve the prognosis in advanced ICC patients with IM, VI, or LM.

Further analysis according to the number of risk factors showed that prognosis became poorer as the number of risk factors increased. However, surgical resection provided a survival benefit to ICC patients regardless of the number of risk factors present. Recently, a 


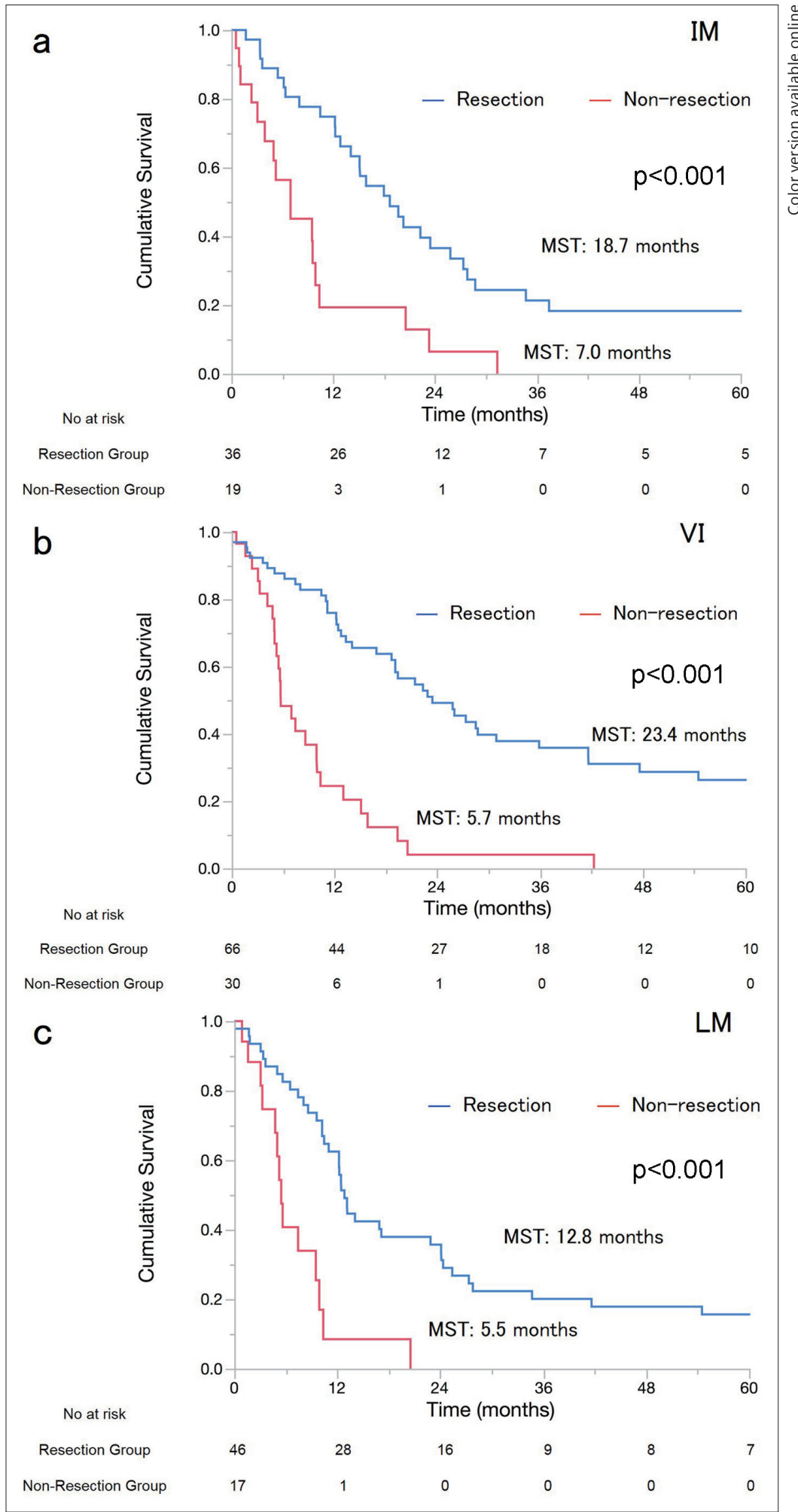

Fig. 1. Survival curves of the resection and non-resection groups stratified by IM, VI, and LM $(\mathrm{a}-\mathrm{c})$. In patients with IM, VI, and LM, MSTs of resected and non-resected patients were 18.7 and $7.1(\mathrm{p}<0.001), 23.4$ and $5.7(\mathrm{p}<0.001)$, and 12.8 and 5.5 months $(\mathrm{p}<0.001)$, respectively. 


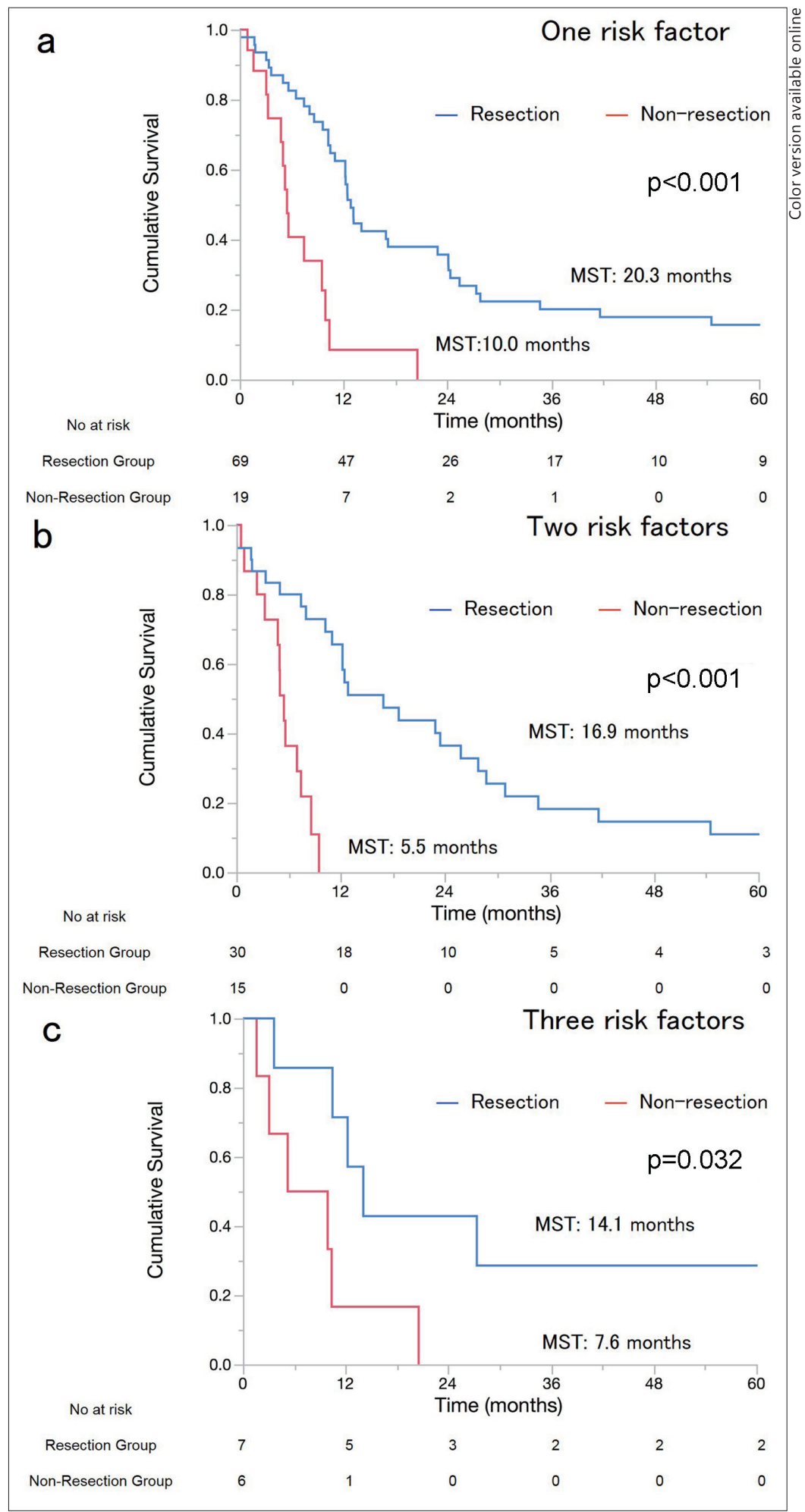

Fig. 2. OS was additionally analyzed according to the number of risk factors present. In patients with one, two, and three risk factors (a-c), MSTs of the resection and nonresection groups were 20.3 vs. 10.0 ( $p<0.001), 16.9$ vs. $5.5(\mathrm{p}<0.001)$, and 14.1 vs. 7.6 months $(\mathrm{p}=0.032)$, respectively. In patients who underwent surgical resection, there was no significant difference in survival among the patients with one, two, and three risk factors $(\mathrm{p}=0.46)$. 
Table 2. Multivariate analysis

\begin{tabular}{llll}
\hline Variable & Hazard ratio & $95 \%$ CI & p-value \\
\hline Surgical resection & 0.32 & $0.19-0.53$ & $<0.001^{*}$ \\
IM & 1.50 & $1.00-2.10$ & 0.051 \\
VI & 1.30 & $0.92-1.84$ & 0.13 \\
LM & 1.87 & $1.25-2.76$ & $0.0024^{*}$ \\
Distant metastasis & 1.19 & $0.70-2.00$ & 0.52 \\
\hline
\end{tabular}

*Significantly different.

new staging system was published by the Liver Cancer Study Group of Japan [15]. According to this new staging system, the presence of IM, VI, or LM strongly influences prognosis. The outcomes for patients with three risk factors were similar to those for stage IV B patients, which is the most advanced class in the new staging system. Surgical resection could provide patients with increased survival over non-surgical treatment even for patients with stage IV B disease. Our data also suggest that when macroscopic curative resection is possible, surgical resection can provide a survival benefit to some patients regardless of the progression of the disease or the disease stage.

In the present study, the sample size was small because of the rarity of ICC. Moreover, because the present study was not controlled by randomization, there was a selection bias between the resection and non-resection groups. Consequently, we conducted an exhaustive systematic literature review to assess the strength of our assertions. Although the 26 previously published studies reported results comparable to ours, they also might have been influenced by biases in patient selection. The present and previous data warrant further prospective studies to confirm the true survival benefits of surgical resection in advanced ICC patients with IM, VI, or LM. Another limitation of this kind of study is that both our data and previous data were from long-term studies. Treatment methods have consistently improved, particularly with regard to non-surgical treatment $[16,17]$, and this could affect the outcomes. Moreover, advances in imaging modalities could have affected patient selection as to whether surgical resection was possible. However, in the current analysis, surgical resection appears to provide survival benefits over non-surgical treatments even for advanced ICC patients with IM, VI, or LM.

In conclusion, surgical resection in ICC patients with IM, VI, or LM is associated with a longer life expectancy. It appears that surgical resection in advanced ICC patients can be justified, despite the recommendations of the EASL guidelines for ICC, and prospective trials to investigate the outcomes of surgical resection in such patients are warranted. 
Table 3. Clinicopathological characteristics, treatment, and clinical outcomes of patients assessed in the 26 index studies

\begin{tabular}{|c|c|c|c|c|c|c|c|c|c|}
\hline \multirow[t]{2}{*}{$\begin{array}{l}\text { Author } \\
\text { (country) }\end{array}$} & \multirow[t]{2}{*}{$\begin{array}{l}\text { Treat- } \\
\text { ment }\end{array}$} & \multirow[t]{2}{*}{$\begin{array}{l}\text { Number } \\
\text { of } \\
\text { patients }\end{array}$} & \multirow[t]{2}{*}{$\begin{array}{l}\text { Mean } \\
\text { age } \\
\text { (years) }\end{array}$} & \multirow[t]{2}{*}{$\begin{array}{l}\text { MST } \\
\text { (months) }\end{array}$} & \multicolumn{2}{|c|}{$\begin{array}{l}\text { OS rate } \\
(\%)\end{array}$} & \multirow[t]{2}{*}{$\begin{array}{l}\text { IM (\%)/ } \\
\text { MST } \\
\text { (months) }\end{array}$} & \multirow[t]{2}{*}{$\begin{array}{l}\text { VI (\%)/ } \\
\text { MST } \\
\text { (months) }\end{array}$} & \multirow[t]{2}{*}{$\begin{array}{l}\text { LM (\%)/ } \\
\text { MST } \\
\text { (months) }\end{array}$} \\
\hline & & & & & $3 y$ & $5 y$ & & & \\
\hline $\begin{array}{l}\text { Uenishi et al. [18] } \\
2014 \text { (Japan) }\end{array}$ & SR & 233 & - & 23.8 & 39 & 31 & $\begin{array}{l}28 / \\
12.5\end{array}$ & $\begin{array}{l}72 / \\
17.2\end{array}$ & $\begin{array}{l}37 / \\
14.3\end{array}$ \\
\hline $\begin{array}{l}\text { Igami et al. [19] } \\
2011 \text { (Japan) }\end{array}$ & SR & 61 & 61 & 24.6 & - & 34 & $\begin{array}{l}31 / \\
-\end{array}$ & $\begin{array}{l}98 / \\
-\end{array}$ & $\begin{array}{l}38 / \\
-\end{array}$ \\
\hline $\begin{array}{l}\text { Nakagohri et al. [13] } \\
2008 \text { (Japan) }\end{array}$ & SR & 56 & 66 & 22 & 42 & 32 & $\begin{array}{l}18 / \\
-\end{array}$ & $\begin{array}{l}-1 \\
-\end{array}$ & $\begin{array}{l}38 / \\
-\end{array}$ \\
\hline $\begin{array}{l}\text { Luo et al. [20] } \\
2014 \text { (China) }\end{array}$ & SR & 1333 & 54 & 14.4 & 25 & 17 & $\begin{array}{l}36 / \\
10\end{array}$ & $\begin{array}{l}15 / \\
14\end{array}$ & $\begin{array}{l}28 / \\
9\end{array}$ \\
\hline $\begin{array}{l}\text { Wang et al. [21] } \\
2013 \text { (China) }\end{array}$ & SR & 367 & $53^{\mathrm{a}}$ & 21 & 41 & 35 & $\begin{array}{l}-1 \\
-\end{array}$ & $\begin{array}{l}15 / \\
-\end{array}$ & $\begin{array}{l}22 / \\
-\end{array}$ \\
\hline $\begin{array}{l}\text { Li et al. [22] } \\
2011 \text { (China) }\end{array}$ & SR & 113 & - & 21 & 27 & 17 & $\begin{array}{l}28 / \\
-\end{array}$ & $\begin{array}{l}22 / \\
-\end{array}$ & $\begin{array}{l}27 / \\
-\end{array}$ \\
\hline $\begin{array}{l}\text { Jiang et al. [7] } \\
2011 \text { (China) }\end{array}$ & SR & 344 & - & 17.6 & 32 & 21 & $\begin{array}{l}25 / \\
12.3\end{array}$ & $\begin{array}{l}17 / \\
11.4\end{array}$ & $\begin{array}{l}-/ \\
-\end{array}$ \\
\hline $\begin{array}{l}\text { Cho et al. [23] } \\
2010 \text { (Korea) }\end{array}$ & SR & 63 & 61 & 25.5 & 51 & 32 & $\begin{array}{l}32 / \\
14.5\end{array}$ & $\begin{array}{l}-1 \\
-\end{array}$ & $\begin{array}{l}30 / \\
5\end{array}$ \\
\hline $\begin{array}{l}\text { Choi et al. [24] } \\
2009 \text { (Korea) }\end{array}$ & SR & 64 & 61 & 39 & 53 & 40 & $\begin{array}{l}11 / \\
-\end{array}$ & $\begin{array}{l}58 / \\
-\end{array}$ & $\begin{array}{l}27 / \\
-\end{array}$ \\
\hline $\begin{array}{l}\text { Paik et al. [25] } \\
2008 \text { (Korea) }\end{array}$ & SR & 97 & 57 & 53 & 53 & 31 & $\begin{array}{l}10 / \\
9.5\end{array}$ & $\begin{array}{l}-1 \\
-\end{array}$ & $\begin{array}{l}24 / \\
6.5\end{array}$ \\
\hline $\begin{array}{l}\text { Bhudhisawasdi [26] } \\
2012 \text { (Thailand) }\end{array}$ & SR & 171 & 56 & 7.6 & 19 & 13 & $\begin{array}{l}37 / \\
-\end{array}$ & $\begin{array}{l}85 / \\
-\end{array}$ & $\begin{array}{l}-1 \\
-\end{array}$ \\
\hline $\begin{array}{l}\text { Ribero et al. [4] } \\
2012 \text { (Italy) }\end{array}$ & SR & 434 & $65^{\mathrm{a}}$ & 33 & 47 & 33 & $\begin{array}{l}32 / \\
-\end{array}$ & $\begin{array}{l}53 / \\
-\end{array}$ & $\begin{array}{l}26 / \\
-\end{array}$ \\
\hline $\begin{array}{l}\text { Guglielmi et al. [27] } \\
2009 \text { (Italy) }\end{array}$ & SR & 52 & 66 & 40 & 50 & 20 & $\begin{array}{l}21 / \\
24\end{array}$ & $\begin{array}{l}-/ \\
17\end{array}$ & $\begin{array}{l}27 / \\
19\end{array}$ \\
\hline $\begin{array}{l}\text { Lang et al. [28] } \\
2009 \text { (Germany) }\end{array}$ & SR & 83 & - & 26 & 38 & 21 & $\begin{array}{l}42 / \\
-\end{array}$ & $\begin{array}{l}41 / \\
-\end{array}$ & $\begin{array}{l}34 / \\
-\end{array}$ \\
\hline $\begin{array}{l}\text { Farges et al. [5] } \\
2011 \text { (France) }\end{array}$ & SR & 212 & 63 & 28 & 43 & 28 & $\begin{array}{l}59 / \\
21\end{array}$ & $\begin{array}{l}44 / \\
22\end{array}$ & $\begin{array}{l}37 / \\
15\end{array}$ \\
\hline $\begin{array}{l}\text { Tamandl et al. [29] } \\
2009 \text { (Austria) }\end{array}$ & SR & 69 & - & 25.5 & 35 & - & $\begin{array}{l}29 / \\
-\end{array}$ & $\begin{array}{l}18 / \\
-\end{array}$ & $\begin{array}{l}19 / \\
-\end{array}$ \\
\hline $\begin{array}{l}\text { Hyder et al. [30] } \\
2014 \text { (US) }\end{array}$ & SR & 514 & $59^{a}$ & 38.8 & 52 & 40 & $\begin{array}{l}25 / \\
-\end{array}$ & $\begin{array}{l}24 / \\
-\end{array}$ & $\begin{array}{l}18 / \\
-\end{array}$ \\
\hline $\begin{array}{l}\text { Fisher et al. [31] } \\
2012 \text { (US) }\end{array}$ & SR & 58 & $66^{\mathrm{a}}$ & 23 & - & - & $21 /$ & $\begin{array}{l}40 / \\
9.6\end{array}$ & $\begin{array}{l}34 / \\
10.7\end{array}$ \\
\hline $\begin{array}{l}\text { Endo et al. [32] } \\
2008 \text { (US) }\end{array}$ & SR & 82 & - & 36 & - & - & $\begin{array}{l}35 / \\
8\end{array}$ & $\begin{array}{l}32 / \\
13\end{array}$ & $\begin{array}{l}9 / \\
7\end{array}$ \\
\hline $\begin{array}{l}\text { Spolverato et al. [33] } \\
2014 \text { (MN) }\end{array}$ & SR & 557 & $60^{\mathrm{a}}$ & 26.9 & 38 & 23 & $\begin{array}{l}-1 \\
-\end{array}$ & $\begin{array}{l}39 / \\
-\end{array}$ & $\begin{array}{l}21 / \\
-\end{array}$ \\
\hline $\begin{array}{l}\text { de Jong et al. [6] } \\
2011 \text { (MN) }\end{array}$ & SR & 449 & $61^{a}$ & 27.3 & 44 & 31 & $\begin{array}{l}27 / \\
19\end{array}$ & $\begin{array}{l}31 / \\
20.0\end{array}$ & $\begin{array}{l}30 / \\
22.9\end{array}$ \\
\hline $\begin{array}{l}\text { Park et al. [34] } \\
2010 \text { (Korea) }\end{array}$ & IAT & 72 & 64 & 12.2 & - & - & $\begin{array}{l}57 / \\
-\end{array}$ & $\begin{array}{l}-1 \\
-\end{array}$ & $\begin{array}{l}-1 \\
-\end{array}$ \\
\hline $\begin{array}{l}\text { Vogl et al. [35] } \\
2012 \text { (Germany) }\end{array}$ & IAT & 115 & 60 & 13 & 10 & - & $\begin{array}{l}70 / \\
-\end{array}$ & $\begin{array}{l}-1 \\
-\end{array}$ & $\begin{array}{l}-1 \\
-\end{array}$ \\
\hline $\begin{array}{l}\text { Hyder et al. [36] } \\
2013 \text { (US) }\end{array}$ & IAT & 198 & $61^{a}$ & 13.2 & 22 & 16 & $\begin{array}{l}53 / \\
-\end{array}$ & $\begin{array}{l}10 / \\
-\end{array}$ & $\begin{array}{l}11 / \\
-\end{array}$ \\
\hline $\begin{array}{l}\text { Chen et al. [37] } \\
2010 \text { (China) }\end{array}$ & $\mathrm{RT}$ & 84 & - & 6.8 & - & - & $\begin{array}{l}25 / \\
5.2\end{array}$ & $\begin{array}{l}-1 \\
-\end{array}$ & $\begin{array}{l}85 / \\
5.9\end{array}$ \\
\hline $\begin{array}{l}\text { Kim et al. [14] } \\
2013 \text { (Korea) } \\
\end{array}$ & $\mathrm{CT}$ & 67 & $58^{\mathrm{a}}$ & 6.2 & - & - & $\begin{array}{l}60 / \\
- \\
\end{array}$ & $\begin{array}{l}-1 \\
- \\
\end{array}$ & $\begin{array}{l}82 / \\
- \\
\end{array}$ \\
\hline
\end{tabular}

a Age was described as median age. MST=median survival time; $3 y=3$ year; $5 y=5$ year; $S R=$ surgical resection; $\mathrm{MN}=$ multinational; $\mathrm{IAT}=$ intra-arterial therapy; $\mathrm{RT}=$ radiotherapy; $\mathrm{CT}=$ chemotherapy. 


\section{Disclosures}

The authors declare that there are no conflicts of interest.

\section{References}

1 Aljiffry M, Abdulelah A, Walsh M, Peltekian K, Alwayn I, Molinari M: Evidence-based approach to cholangiocarcinoma: a systematic review of the current literature. J Am Coll Surg 2009;208:134-147.

2 Ikai I, Arii S, Okazaki M, Okita K, Omata M, Kojiro M, Takayasu K, Nakanuma Y, Makuuchi M, Matsuyama Y, Monden M, Kudo M: Report of the 17th Nationwide Follow-up Survey of Primary Liver Cancer in Japan. Hepatol Res 2007;37:676-691.

3 Nathan H, Pawlik TM, Wolfgang CL, Choti MA, Cameron JL, Schulick RD: Trends in survival after surgery for cholangiocarcinoma: a 30-year population-based SEER database analysis. J Gastrointest Surg 2007;11:1488-1496, discussion 1496-1497.

4 Ribero D, Pinna AD, Guglielmi A, Ponti A, Nuzzo G, Giulini SM, Aldrighetti L, Calise F, Gerunda GE, Tomatis M, Amisano M, Berloco P, Torzilli G, Capussotti L, Italian Intrahepatic Cholangiocarcinoma Study Group: Surgical approach for long-term survival of patients with intrahepatic cholangiocarcinoma: a multi-institutional analysis of 434 patients. Arch Surg 2012;147:1107-1113.

5 Farges O, Fuks D, Boleslawski E, Le Treut YP, Castaing D, Laurent A, Ducerf C, Rivoire M, Bachellier P, Chiche L, Nuzzo G, Regimbeau JM: Influence of surgical margins on outcome in patients with intrahepatic cholangiocarcinoma: a multicenter study by the AFC-IHCC-2009 study group. Ann Surg 2011;254:824-829, discussion 830 .

6 de Jong MC, Nathan H, Sotiropoulos GC, Paul A, Alexandrescu S, Marques H, Pulitano C, Barroso E, Clary BM, Aldrighetti L, Ferrone CR, Zhu AX, Bauer TW, Walters DM, Gamblin TC, Nguyen KT, Turley R, Popescu I, Hubert C, Meyer S, Schulick RD, Choti MA, Gigot JF, Mentha G, Pawlik TM: Intrahepatic cholangiocarcinoma: an international multi-institutional analysis of prognostic factors and lymph node assessment. J Clin Oncol 2011;29:3140-3145.

7 Jiang W, Zeng ZC, Tang ZY, Fan J, Sun HC, Zhou J, Zeng MS, Zhang BH, Ji Y, Chen YX: A prognostic scoring system based on clinical features of intrahepatic cholangiocarcinoma: the Fudan score. Ann Oncol 2011;22:1644-1652.

8 Bridgewater J, Galle PR, Khan SA, Llovet JM, Park JW, Patel T, Pawlik TM, Gores GJ: Guidelines for the diagnosis and management of intrahepatic cholangiocarcinoma. J Hepatol 2014;60:1268-1289.

9 Amini N, Ejaz A, Spolverato G, Kim Y, Herman JM, Pawlik TM: Temporal trends in liver-directed therapy of patients with intrahepatic cholangiocarcinoma in the United States: a population-based analysis. J Surg Oncol 2014;110:163-170.

10 Edge SB, Compton CC: The American Joint Committee on Cancer: The 7th edition of the AJCC cancer staging manual and the future of TNM. Ann Surg Oncol 2010;17:1471-1474.

11 Seo S, Hatano E, Higashi T, Nakajima A, Nakamoto Y, Tada M, Tamaki N, Iwaisako K, Mori A, Doi R, Ikai I, Uemoto S: Fluorine-18 fluorodeoxyglucose positron emission tomography predicts lymph node metastasis, P-glycoprotein expression, and recurrence after resection in mass-forming intrahepatic cholangiocarcinoma. Surgery 2008;143:769-777.

12 Yamanaka K, Hatano E, Kanai M, Tanaka S, Yamamoto K, Narita M, Nagata H, Ishii T, Machimoto T, Taura K, Uemoto S: A single-center analysis of the survival benefits of adjuvant gemcitabine chemotherapy for biliary tract cancer. Int J Clin Oncol 2014;19:485-489.

13 Nakagohri T, Kinoshita T, Konishi M, Takahashi S, Gotohda N: Surgical outcome and prognostic factors in intrahepatic cholangiocarcinoma. World J Surg 2008;32:2675-2680.

14 Kim YI, Park JW, Kim BH, Woo SM, Kim TH, Koh YH, Lee WJ, Kim CM: Outcomes of concurrent chemoradiotherapy versus chemotherapy alone for advanced-stage unresectable intrahepatic cholangiocarcinoma. Radiat Oncol 2013;8:292.

15 Sakamoto Y, Kokudo N, Matsuyama Y, Sakamoto M, Izumi N, Kadoya M, Kaneko S, Ku Y, Kudo M, Takayama T, Nakashima 0, Liver Cancer Study Group of Japan: Proposal of a new staging system for intrahepatic cholangiocarcinoma: analysis of surgical patients from a nationwide survey of the Liver Cancer Study Group of Japan. Cancer 2016;122:61-70.

16 Eckel F, Schmid RM: Chemotherapy in advanced biliary tract carcinoma: a pooled analysis of clinical trials. Br J Cancer 2007;96:896-902.

17 Valle J, Wasan H, Palmer DH, Cunningham D, Anthoney A, Maraveyas A, Madhusudan S, Iveson T, Hughes S, Pereira SP, Roughton M, Bridgewater J, ABC-02 Trial Investigators: Cisplatin plus gemcitabine versus gemcitabine for biliary tract cancer. N Engl J Med 2010;362:1273-1281.

18 Uenishi T, Ariizumi S, Aoki T, Ebata T, Ohtsuka M, Tanaka E, Yoshida H, Imura S, Ueno M, Kokudo N, Nagino M, Hirano S, Kubo S, Unno M, Shimada M, Yamaue H, Yamamoto M, Miyazaki M, Takada T: Proposal of a new staging system for mass-forming intrahepatic cholangiocarcinoma: a multicenter analysis by the Study Group for Hepatic Surgery of the Japanese Society of Hepato-Biliary-Pancreatic Surgery. J Hepatobiliary Pancreat Sci 2014;21:499-508. 
19 Igami T, Ebata T, Yokoyama Y, Sugawara G, Takahashi Y, Nagino M: Staging of peripheral-type intrahepatic cholangiocarcinoma: appraisal of the new TNM classification and its modifications. World J Surg 2011;35:2501-2509.

20 Luo X, Yuan L, Wang Y, Ge R, Sun Y, Wei G: Survival outcomes and prognostic factors of surgical therapy for all potentially resectable intrahepatic cholangiocarcinoma: a large single-center cohort study. J Gastrointest Surg 2014;18:562-572.

21 Wang Y, Li J, Xia Y, Gong R, Wang K, Yan Z, Wan X, Liu G, Wu D, Shi L, Lau W, Wu M, Shen F: Prognostic nomogram for intrahepatic cholangiocarcinoma after partial hepatectomy. J Clin Oncol 2013;31:1188-1195.

22 Li YY, Li H, Lv P, Liu G, Li XR, Tian BN, Chen DJ: Prognostic value of cirrhosis for intrahepatic cholangiocarcinoma after surgical treatment. J Gastrointest Surg 2011;15:608-613.

23 Cho SY, Park SJ, Kim SH, Han SS, Kim YK, Lee KW, Lee SA, Hong EK, Lee WJ, Woo SM: Survival analysis of intrahepatic cholangiocarcinoma after resection. Ann Surg Oncol 2010;17:1823-1830.

24 Choi SB, Kim KS, Choi JY, Park SW, Choi JS, Lee WJ, Chung JB: The prognosis and survival outcome of intrahepatic cholangiocarcinoma following surgical resection: association of lymph node metastasis and lymph node dissection with survival. Ann Surg Oncol 2009;16:3048-3056.

25 Paik KY, Jung JC, Heo JS, Choi SH, Choi DW, Kim YI: What prognostic factors are important for resected intrahepatic cholangiocarcinoma? J Gastroenterol Hepatol 2008;23:766-770.

26 Bhudhisawasdi V, Talabnin C, Pugkhem A, Khuntikeo N, Seow OT, Chur-in S, Pairojkul C, Wongkham S: Evaluation of postoperative adjuvant chemotherapy for intrahepatic cholangiocarcinoma patients undergoing R1 and R2 resections. Asian Pac J Cancer Prev 2012;13(Suppl):169-174.

27 Guglielmi A, Ruzzenente A, Campagnaro T, Pachera S, Valdegamberi A, Nicoli P, Cappellani A, Malfermoni G, Iacono C: Intrahepatic cholangiocarcinoma: prognostic factors after surgical resection. World J Surg 2009;33:1247-1254.

28 Lang H, Sotiropoulos GC, Sgourakis G, Schmitz KJ, Paul A, Hilgard P, Zöpf T, Trarbach T, Malagó M, Baba HA, Broelsch CE: Operations for intrahepatic cholangiocarcinoma: single-institution experience of 158 patients. J Am Coll Surg 2009;208:218-228.

29 Tamandl D, Kaczirek K, Gruenberger B, Koelblinger C, Maresch J, Jakesz R, Gruenberger T: Lymph node ratio after curative surgery for intrahepatic cholangiocarcinoma. Br J Surg 2009;96:919-925.

30 Hyder O, Marques H, Pulitano C, Marsh JW, Alexandrescu S, Bauer TW, Gamblin TC, Sotiropoulos GC, Paul A, Barroso E, Clary BM, Aldrighetti L, Ferrone CR, Zhu AX, Popescu I, Gigot JF, Mentha G, Feng S, Pawlik TM: A nomogram to predict long-term survival after resection for intrahepatic cholangiocarcinoma: an Eastern and Western experience. JAMA Surg 2014;149:432-438.

31 Fisher SB, Patel SH, Ko oby DA, Weber S, Bloomston M, Cho C, Hatzaras I, Schmidt C, Winslow E, Staley CA 3rd, Maithel SK: Lymphovascular and perineural invasion as selection criteria for adjuvant therapy in intrahepatic cholangiocarcinoma: a multi-institution analysis. HPB (Oxford) 2012;14:514-522.

32 Endo I, Gonen M, Yopp AC, Dalal KM, Zhou Q, Klimstra D, D’Angelica M, DeMatteo RP, Fong Y, Schwartz L, Kemeny N, O’Reilly E, Abou-Alfa GK, Shimada H, Blumgart LH, Jarnagin WR: Intrahepatic cholangiocarcinoma: rising frequency, improved survival, and determinants of outcome after resection. Ann Surg 2008;248:84-96.

33 Spolverato G, Kim Y, Alexandrescu S, Popescu I, Marques HP, Aldrighetti L, Clark Gamblin T, Miura J, Maithel SK, Squires MH, Pulitano C, Sandroussi C, Mentha G, Bauer TW, Newhook T, Shen F, Poultsides GA, Wallis Marsh J, Pawlik TM: Is hepatic resection for large or multifocal intrahepatic cholangiocarcinoma justified? Results from a multi-institutional collaboration. Ann Surg Oncol 2015;22:2218-2225.

34 Park SY, Kim JH, Yoon HJ, Lee IS, Yoon HK, Kim KP: Transarterial chemoembolization versus supportive therapy in the palliative treatment of unresectable intrahepatic cholangiocarcinoma. Clin Radiol 2011;66:322-328.

35 Vogl TJ, Naguib NN, Nour-Eldin NE, Bechstein WO, Zeuzem S, Trojan J, Gruber-Rouh T: Transarterial chemoembolization in the treatment of patients with unresectable cholangiocarcinoma: results and prognostic factors governing treatment success. Int J Cancer 2012;131:733-740.

36 Hyder O, Marsh JW, Salem R, Petre EN, Kalva S, Liapi E, Cosgrove D, Neal D, Kamel I, Zhu AX, Sofocleous CT, Geschwind JF, Pawlik TM: Intra-arterial therapy for advanced intrahepatic cholangiocarcinoma: a multiinstitutional analysis. Ann Surg Oncol 2013;20:3779-3786.

37 Chen YX, Zeng ZC, Tang ZY, Fan J, Zhou J, Jiang W, Zeng MS, Tan YS: Determining the role of external beam radiotherapy in unresectable intrahepatic cholangiocarcinoma: a retrospective analysis of 84 patients. BMC Cancer 2010;10:492. 